\title{
IMPACT OF COVID-19 ON UNIVERSITY EDUCATION IN NIGERIA
}

\author{
Dr. (Mrs.) Stella-Maris Aki Okey \\ Head of Department, Educational Management, \\ Faculty of Education, Cross River University of Technology, Calabar \\ Email: stellamarisegim@gmail.com
}

\begin{abstract}
COVID-19's impacts on the socio-economic activities across the globe have been gruesome, horrifying, dramatic and traumatic for every human being. The purpose of the study is to reexamine the impact of the novel coronavirus (COVID-19) on university education in Nigeria.

The research sample consisted of five males and five females aged 18-35 years who were undergraduates from different tertiary institutions in Nigeria. Purposive sampling was used. In-depth interviews were used to collect primary data that were carefully analyzed using the five steps of qualitative data analysis.

Findings revealed that the impact of COVID-19 affected higher institutions in Nigeria through the total lockdown of schools, reduction of international education, disruption of academic calendar of higher institution, creating teaching and learning gap between students and lecturers in universities and cut budget for education which stands at $7.00 \%$ of the total national budget in Nigeria. Further findings identified some reoccurring challenges facing the online or virtual learning adopted by most universities in Nigeria as respondents briefly listed (1) poor network connectivity and infrastructure (2) lack of concentration and comprehension of course content.
\end{abstract}

Keywords: COVID-19 pandemic, Nigerian Educational System, E-learning, lockdown, newnormal 


\subsection{Introduction}

Coronavirus outbreak has become one of the most notorious events of the decade. The word corona means a "crown' in Latin. Coronaviruses got their name from the way that they look under a microscope. The virus consists of a core of genetic material surrounded by an envelope with protein spikes. This gives it the appearance of a crown.

Coronavirus is zootomic meaning that the viruses are transmitted between animals and humans and between humans and humans. The virus infects people of all ages. The virus spreads primarily when people are in very close physical contact and one person inhales small droplets produced by an infected person through coughing, sneezing, talking or singing. It can also be transmitted through touching of contaminated surfaces such as tables, door handles, chairs, cabinets etc. which could lead to death if not properly managed.

The novel coronavirus originated from the human sea food market at Wuhan, China where bats, snakes, and other animals are sold and has rapidly engulfed the entire world except for these twelve (12) countries in Asia and Oceania, North Korea, Turkmenistan, The Solomon Islands, Vanuatu, Samoa, Kibibati, Federated States of Micronesia, Tonga, The Marshall Islands, Palau, Tuvalu, Nauru.

It is therefore not surprising that the World Health Organization (WHO) on January 30, 2020 declared the coronavirus disease 2019 (COVID -19) a pandemic. What is a pandemic? A pandemic is defined as an occurrence of disease that affects over a wide geographic area and affecting an exceptionally high proportion of the population. The last pandemic reported was the influenza type A referred to as H1N1, a respiratory infection known as " swine flu ", caused by pigs which spread to only seventy-eight (78) countries in the world in 2009 and its effect was not as devastating and dangerous as coronavirus disease. This novel disease was named Coronavirus Disease 2019 (COVID-19) by the WHO in February 2020 and has affected almost all countries in the world with several fatalities. World data on COVID-19 indicates, 24,487, 383 confirmed cases, 832,002 deaths and lamentably 35, 571, 79 newly confirmed cases in the last 14 days as at 28/08/2020 (https://www.ecdc.europa.eu. Retrieved 29/08/2020). In Nigeria, records show 53, 477 confirmed cases, 41,017 discharged cases and 1,011 deaths recorded in 36 States and the Federal Capital Territory, Abuja (http://nairametrics.com Retrieved 29/08/2020).

\subsection{Objective of the Study}

The general objective of the study is to critically evaluate the current upsurge of the novel coronavirus (COIVID-19) pandemic on university education in Nigeria. Specifically, to

1. Examine the impact of COVID-19 on university education in Nigeria.

2. Identify and pinpoint current challenges triggered by the emergence of the monster COVID-19.

3. Make available through the findings of this study verified and relevant information that will aid policy-makers in all sectors, more specifically in the educational sector as concern. 


\subsection{Conceptual Review}

\subsection{The emergence of COVID-19 in Nigeria}

Nigeria was not spared from this deadly virus as the Federal Ministry of Health on the $27^{\text {th }}$ Of February, 2020 confirmed and announced the first case of coronavirus disease in Lagos State. The Minister for Health announced the formation of the Nigeria Centre for Disease Control (NCDC) to control and manage the situation across the country.

To curb the ravaging spread of COVID-19, the Federal Ministry of Education issued a circular for the closure of all schools for one month with effect from $23^{\text {rd }}$ of March 2020. Since then, schools in Nigeria have remained closed until early September when students in the exit classes in the primary and secondary schools were asked to return to school to enable them write their external examinations. More so, in order to check the spread of the virus, the use of nose mask/face shield, alcohol based hand sanitizers, running water with soap and other preventive measures came as a pre-requite for school's resumption. It is sad to note that the reported cases from various states of the Federation show cases of COVID-19 infections among students upon resumption for examination. This is as a result of negligence on the part of some schools to do the needful. In view of the above, reopening schools fully will put our students (children) and the country at large to a very high health risk.

It should quickly be pointed out that attempts were made to engage our students on the online teaching and learning but are faced with several challenges ranging from lack of money to purchase smart phones, buy data, poor GSM network, and inadequate electricity to power the phones and lack of technical knowledge to operate the phones. The reasons for these challenges are not far-fetched. This is because government at all levels have in all the years failed to implement the wonderful contents in the National Policy of Education which is the blue print of education in Nigeria due to lack of political will by our leaders. This is evident in the poor funding and least attention given to education as exposed by COVID-19. The bitter truth is that COVID-19 has further revealed the crisis within the education sector in Nigeria as governments, and educational institutions including stakeholders struggle to adjust to a "New Normal'" in the face of uncertainties. It is a statement of fact that education is the master key to individual, national and global development. This is why The United Nations Educational Scientific and Cultural Organization (UNESCO) has recommended an allocation of at least $26 \%$ of national budgets to this critical sector. But what does government in Nigeria do? The Federal government Budget allocation to the Education Sector (2009-2018) range between $7.25 \%$ and $7.00 \%$.

\subsection{COVID-19 Symptoms and Medical Guidelines for Control and Prevention}

Symptoms of COVID-19 include the following: fever, dry cough, tiredness, aches and pains, sore throat, diarrhea, conjunctivitis, headaches, chest pain, and dehydration. A few cases have recorded the following: Difficulty in breathing, persistence pressure in the chest, new confusion or inability to arise and bluish lips or face.

Symptoms may develop two (2) days to two weeks (14) days following exposure to the virus. Coronavirus spreads more but kills less, unlike the Severe Acute Respiratory Syndromes (SARS) which took place between 2002/2003 that spreads less but kills more.

In view of the above, the WHO advised for high-risk population thus: 
- When having visitors at your home, extend one - meter greetings; like a wave, nod or bow.

- Request that visitors and those who live with you wash their hands under running water and soap for at least 10 seconds every 2hours. But, in the absence of running water should use alcohol based hand sanitizers frequently.

- Ensure good ventilation in indoor setting including homes and offices.

- Clean and disinfect surfaces in your home and offices (especially those that people touch a lot) on a regular basis.

- Limit shared spaces if someone you live with is not feeling well especially with possible COVID-19 symptoms.

- If you show symptoms of COVID-19 illness, contact your health care provider by telephone, before visiting your healthcare facility.

- Have an action plan in preparation for an outbreak of COVID- 19 in your community.

- When you are in public, practice the same guidelines as you would at home.

- Make use of facemask/ shield

- Keep updated on COVID-19 through getting information from reliable sources (WHO, National Center for Disease Control (NCDC), Federal Ministry of Health, Abuja).

\subsection{Pandemic and Closure of Schools in Nigeria}

On march 19, 2020 Nigeria government through the Federal Ministry of Education ordered the total closure of schools at all level as one of the control measures to prevent the deadly spread of the virus. There is no doubt that the disruption and sudden interference of the pandemic has caused insurmountable challenges on the Nigerian education system. Statistically, it is glaring that the educational sector is the casualty of this monstrous carnage permeating the global space. Even after the gradual reopening of both human and economic activities as a sustainable strategy as ordered by the President on April 27, 2020 the educational sector remains sealed, being considered to be in the last phase of the total if not partial easing of the lockdown measure.

The COVID-19 pandemic is surely not the last crisis that will threaten school continuity in Nigeria, given the increase in the number of infectious diseases worldwide, or the conflict in the North East (Thelma \&Adeneji, 2020). Six months after closure of schools in Nigeria, why this long break or stay at home of our students? There have been series of attempts by the Federal government to reopen schools but to no avail. The Federal government has set out some conditions for reopening of schools; fumigate the schools and keep them in clean sanitary state, provision of hand washing facilities at various places within the school, use of alcoholic based hand sanitizers, use of nose mask/face shield by staff and students, enough space for physical distancing etc. How many schools especially the public schools have met with these conditions? How do you comply with maintaining physical distancing in crowded classes of students? How do you comply with hand washing in schools/ areas without steady water supply? How do you ensure the proper use of face nose mask/face shield in our over populated schools? How many testing facilities are available for each of our overcrowded schools? How trained are our teachers, non-teaching staff and school administrators to manage this new normal situation? Are there health facilities and isolation centers in schools in case an infected person is dictated? And the most worrisome question is: are our health 
facilities/ personnel adequate and well prepared to face the sudden and devastating second phase of COVID-19 pandemic? These are some of the questions begging for answers.

It is not just enough for students to return to school but the atmosphere and conditions must also be safe for effective teaching and learning. Evidence across the country abound that most schools from nursery to tertiary are not ready for resumption, yet, there have been agitations from different quarters including teachers' unions, students, parents etc calling for a total reopening of schools. Records have it that schools reopening in some more developed areas such as Israel, Jamaica, South Africa to mention but a few led to sudden increase of the infection in less than a week after resumption of schools and schools were shut down again. Is this the kind of experience we want to have in Nigeria before we take the right steps?

Comparing market places and religious places of worship to schools to my mind is very shallow. It is a basic fact that it is not compulsory to go to the market or place of worship and you may not be punished for that. You may decide to go to a market that is not thickly populated, make purchases and leave. For sellers, they can also determine on how to manage their customers. In addition, they are operated by adults who can manage themselves. It should also be recalled that the markets were not all open to business suddenly, it was done gradually. Same with places of worship even till date. Sadly, opening of the market and religious places has led to a significant increase of infected persons and deaths. On the other hand, students are thickly populated in schools and their classes coupled with inadequate infrastructures, are hyper active and so will find it difficult to adhere to social distancing. Furthermore, they are expected to spend most part of their day in school. The argument here is not that schools shouldn't be reopened but that adequate preparations should be made in line with what was done before the airports were open for business to ensure that students and staff are safe. It is pertinent to observe at this juncture not all the International flights have commenced operations in Nigeria since the lockdown. Why?

\subsection{Impact of the Pandemic on Education and Learners Welfare}

Children on the higher end of the socio-economic spectrum may experience less disruption to their learning because their private schools are well-equipped with ICT infrastructure and they can afford remote learning resources at home. The majority that would be left struggling are the students from vulnerable and disadvantaged backgrounds who do not have access to computer $\mathrm{s}$ and other devices outside school. In many cases, these children live in communities with poor or non-existent connectivity and unreliable power supply. Inevitably, this digital divide will exacerbate the learning disparities among these children (Taibat Aduragba, 2020). There is no shying away from the fact that most of the problems we are seeing today in all sectors of the economy are the full harvest of what we planted in the past in the education sector. As a result of the long stay at home, our children have been exposed to various high risk activities and social vices such as rape, gangsterism, smoking, cultism, robbery, prostitution, ritual killings, suicide, kidnapping, 419, etc. This is as a result of the long stay at home as the saying goes that "'an idle mind is the devil's workshop". By this, it is imperative that we should re-direct out efforts to less risky programs and activities that will keep our students/children engaged thereby making them creative, innovative and technologically inclined to meet up with the new normal situation globally. It is on record that majority of our university graduates have for several years been either unemployed or underemployed in the normal situation. What now happens with the COVID-19 pandemic which has led to the decline of economic activities globally and none is sure of when this end. There was a general a consensus among top economists that the coronavirus pandemic will 
plunge the world into a global recession (Ozili Peterson, 2020). Your guess is as good as mine. What can be done to ease this situation? This is where literacy education comes into play.

Education is the total transformation of an individual positively to enable him/her contributes towards the development of a nation. It involves the acquisition of basic skills such as ability to read, write, reason, see and put things together to arrive at something positive. Literacy is the ability to read and write. It is also the ability to use one's skills and talents for self and national development. Going by these definitions, it is a truism that our children are literates and educated to add value to the society. Observations during this period of closure of schools show that there are students who have meaningfully engaged themselves in discovering and developing their hidden talents through the power of literacy. Such hidden talents are the release of debut albums, fashion designing, photography, driving skills, buying and selling of materials, hair dressing, professional dancing, bead making, dry cleaning, online trading, organizing home lessons, baking, cooking, reading/writing skills/ book presentations to mention but a few. In fact, the utilization of these talents by some of these students at home has started bringing some bread on the dining tables in some homes. To this end, it is evidently clear that our students are filled with potentials that can be used effectively put into use during this new -normal period.

It is on record that the WHO has hinted to the world that COVID-19 is not leaving us soon, hence, there is a need for the government, education stakeholders and parents to take decisive steps in ensuring that programs and activities are put in place to encourage students discover themselves through the power of literacy for self -actualization in this new normal era. These developments should be encouraged through a strong political will such as:

- Encouraging technical know-how by giving of soft loans to develop a business based on the identified skills.

- Ensuring and encouraging facilities for the startup of small medium enterprise (SME).

- Engaging in the continuous creating of awareness and participation of our youths in skill acquisition rather than laying emphasis on acquiring of only certificates for white color jobs that are hardly in existence now.

- Government at all levels should revamp the agricultural and industrial sectors to meet up with the new demands in our society.

- The curriculum of our school system at all level should be tailored towards the current needs of our society in line with the new-normal

- Religious bodies on the other hand should set up vocational schools, lifelong skill acquisition centers that will meet up with the demands of the society.

- Well meaning individuals and philanthropists should establish companies, industries, factories, to train our children in various skills and talents. This will make them develop themselves as well as become entrepreneurs to employ others.

\subsection{Study Methodology}

This offers direction on how the research should conduct the study.

\subsection{Qualitative Research}

Punch (1998, p.4) defined qualitative research as "an empirical research where the data are not in the form of numbers." The qualitative researcher is concerned with understanding 
people's experiences in context (Van Maaneen, 1990). The study was interested in understanding the experiences of students in tertiary institution in Nigeria affected by the COVID-19 crisis. Therefore, a qualitative method assisted the researcher to explore those experiences and allowed students from carefully selected universities in Nigeria to share their stories of staying out of school for over a period of 9 months was deemed appropriate.

\subsection{Selection of Participants}

The study purposefully selected 10 participants each from different university within Nigeria (i.e. five males and five females) to take part in the study. The age group of the participates ranged from 18-35 years of age and all of them were undergraduates as at the time of interview which took place from $13^{\text {th }}$ to $20^{\text {th }}$ of November 2020 . Purposive sampling method was applied to select the participants because it allowed for the selection of suitable people for the purpose of the study.

\subsection{Ethical Approval}

Privacy and confidentiality of the participants were maintained, as the names of the interviewees and other data perceived to be sensitive and personal are not included in this study.

\subsection{Data Collection}

The data were extracted by using in-depth interview, which were both structured and unstructured, allowing the respondents to reveal their own thoughts and ideas and this helped the researcher to obtain more information on their beliefs and attitudes than would be possible from other data gathering methods.

\subsection{Data Analysis}

In this study data were analyzed using the steps of qualitative data analysis identified by Terre Blenche, Durrhelm and Painter (2006).

\section{Step 1: Familiarization and immersion}

During this phase the researcher concentrated on gaining a thorough understanding of the field notes, voice recorder and interview transcripts.

\section{Step 2: Including themes}

Second, once the content of the data was summarized, it was categorized into coded themes such as implications of the COVID-19 pandemic on leaner's, health safety, violence and crime.

\section{Step 3: Coding}

Coding systems are typically used to break down qualitative data into useful units that can be assimilated in new ways that allow a systemic, dense explanatory theory to develop (Priest, Roberts, \& Woods, 2000).

\section{Step 4: Elaboration}

When collecting materials for interpretative analysis, one experiences events or things people say in linear and chronological order. 


\section{Step 5: Interpretation and checking}

The study combined all the interpretations collected. This is the stage where the researcher made sense of the data and its meaning by transcribing the findings collected during the study concerning the impact of COVID-19 on university education in Nigeria

\subsection{Findings and discussion}

With sad expression in their voices and words, participants asserted to the varying degree to which the COVID-19 pandemic had irreparably detoured and gruesomely affected their university education, and was also described as a sudden disruption and interference in learning.

Furthermore, participants confirmed that the uncertainty of the future caused by the pandemic created fear, frustration and anger that fostered domestic and communal violence, substance abuse, and prostitution, drug trafficking and sometimes even suicide during the COVID-19 lockdown. While some respondents equally experienced hope in the gradual resumption of lectures, noting that their schools were able to adopt the online learning policy. But then, complained bitterly of the difficulties confronting this new method of learning. When asked to mention some reoccurring challenges facing the online or virtual learning, respondent's briefly listed (1) poor network connectivity and infrastructure (2) lack of concentration and comprehension of course content.

Findings revealed that the COVID-19 pandemic had a negative and gruesome impact on university education in Nigeria.

\subsection{Conclusion}

The COVID-19 pandemic is one which has had a detrimental impact in all sectors of the economy, seriously hindering the normal functionality of our society and therefore resulting in massive hardship across both our economy and public wellbeing. This study is therefore meant to highlight the impact of the novel cornonavirus (COVID-19) on university education in Nigeria, and to also to advance some novel ways in which our students can meaningfully engage themselves during and after the lockdown using their literacy, knowledge and skills to enhance individual and national development instead of just idling away because "'an idle mind is the devil's workshop.',

The Federal government has set out some conditions for reopening of schools; fumigate the schools and keep them in clean sanitary state, provision of hand washing facilities at various places within the school, use of alcoholic based hand sanitizers, use of nose mask/face shield by staff and students, enough space for physical distancing etc. How many schools especially the public schools have met with these conditions? How do you comply with maintaining physical distancing in crowded classes of students? How do you comply with hand washing in schools/ areas without steady water supply? How do you ensure the proper use of face nose mask/face shield in our over populated schools? How many testing facilities are available for each of our overcrowded schools? How trained are our teachers, non-teaching staff and school administrator to manage this new normal situation? Are there health facilities and isolation centers in schools in case an infected person is dictated? And the most worrisome question is: are our health facilities/ personnel adequate and well prepared to face the sudden and devastating second phase of COVID-19 pandemic? These are some of the questions begging for answers. The COVID-19 pandemic is surely not the last crisis that will threaten 
school continuity in Nigeria, given the increase in the number of infectious diseases worldwide, or the conflict in the North East.

\subsection{Recommendations}

Based on the findings, the following recommendations were made: that;

1. The government should as a matter of urgency take proactive steps in ensuring that they comply with the guidelines set to enhance a safe and conducive learning environment for students.

2. The Federal and State governments should increase the budgetary allocation to education to at least $15 \%$ as this will help in providing necessary infrastructures to ease effective learning and teaching.

3. The Federal Government should declare Education a state of emergency for the next five years so that it can channel her attention towards redirecting, correcting and putting it on the same page with education in developed countries.

4. School administrators, teachers and students should undergo training and retraining programs on E-management of schools, E-teaching and learning in line with the newnormal.

5. Blended learning which is a combination of traditional face-face and online learning should be encouraged for now rather than jump straight into online learning alone as this may lead to a lot of frustration on both the teachers and learners.

\section{Suggestions for Further Study}

Based on the outcome of this study, the following are recommended for further study:

1. Coping with the unprecedented challenges of the post-COVID-19 pandemic in Nigeria.

2. A review of the online learning methodology for modification and advancement in the new normal.

Funding: This research received no external funding.

Conflicts of interest: The author declares no conflict of interest. 


\section{References}

Adelakun I. Samuel, (2020). Coronavirus (covid-19) and Nigerian Education System: Impacts, Management, Responses, and Way Forward. Creative Commons Attribution International License, CCBY. DOI: https://doi.org/10.31058/j.edu.2020.34009

ECDC (2021). COVID-19 Situation update for the EA/EEA, as of week 2 2021. Available online: https://www.ecdc.europa.eu.

Nairamatrics (2021). Cost of invermection soar after research suggest $75 \%$ chances of cutting Covid-19 deaths. Available online: http://nairametrics.com

Okey, S.A. (2020). Discovery yourself through the power of literacy in this COVID-19 pandemic era for self-actualization: From the Administrator's Lens. A paper presented to mark the 2020 International Literacy Day ''Literacy the Ultimate investment', 08/09/2020 on SKYPE.

Ozile Peterson, (2020). Covid-19 pandemic crisis: The Nigerian experience and structural causes MPRA paper. Available online: https://mpra.ub.uni-menchen.de/103131.

Ozile, P.K \& Aru, T.G. (2020). Spillover of Covid-19 Impact on the Global Economy. Working paper.

Taibat A, Hussain, (2020). Education and COVID-19 in Nigeria: Tackling the Digital Divide. Education and Covid-19 in Nigeria. Available online https://worldliteracyfoundation.org/education-andcovid19.

Thelma O. \& Adeneji, A., (2020). COVID-19 Impending Situation Threatening to Deepen Nigeria's Education Crisis: Center for the Study of Economic of African CSEA pdf25-18.

The Chinese Preventive Medical Association. An update on the Epidemiological characteristics of Novel Corononavirus pneumonia (Covid-19). Chin j Epidernal, 2020, 41, (2), 139-144.

The Guardian. Don't reopen schools now ASUU president urges Government. Available online: m.guardian.ng/news/don't-reopen-schools-now-asuu-president-urgesgovernment.

UNICEF NIGERIA. Nigeria Education in Emergencies Working Group; Nigeria Education Sector COVID-19 Reponses Strategy in North East. Available online: https://covid19.ncdc.gov.ng.

Wondwosen, T. \& Damtew, T, (2020). Covid19 Poses a Serious Threat to Higher Education: The impact of COVID-19 Crisis; International Network for Higher Education in Africa.

World Health Organization (2020). Coronavirus Disease 2019 (COVID-19) situation report36. Available online: https://www.who.int/docs/default/source/coronavirus(situationreports)covid19 